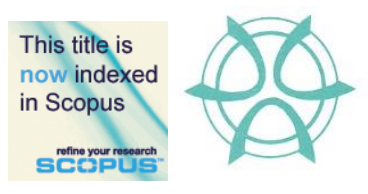

PLANNING MALAYSIA:

Journal of the Malaysian Institute of Planners

VOLUME 15 ISSUE 1 (2017), Page 191 - 200

\title{
REVISITING ANDALUSIAN GARDEN: VISIONS FOR CONTEMPORARY ISLAMIC GARDEN DESIGN
}

\author{
Zainab Abdul Latiff ${ }^{1}, \&$ Maheran Mohd Yaman ${ }^{2}$ \\ ${ }^{1}$ Faculty of Design and Architecture, \\ UNIVERSITI PUTRA MALAYSIA \\ ${ }^{2}$ Kulliyyah of Architecture and Environmental Design, \\ INTERNATIONAL ISLAMIC UNIVERSITY MALAYSIA
}

\begin{abstract}
Andalusian garden is one of the historical gardens in the Muslim world. It appears that the garden designers at the time managed to emulate the spiritual and sacred essence of the paradisiacal environment on earth. The method of content analysis and library search was applied in this study. The findings of this study reveal that the Andalusian garden has been built in accordance with Islamic principles of environment and has crystallized the Quranic paradise description in reality. To conclude, the physical attributes of the Andalusian garden made an essential reference for a contemporary Islamic garden design.
\end{abstract}

Keyword: Andalusian garden, Islamic garden, contemporary garden, environmental principles

Date Received: $30^{\text {th }}$ April 2016

Date of Acceptance: $30^{\text {th }}$ October 2016 
Zainab Abdul Latiff, \& Maheran Mohd Yaman

Revisiting Andalusian Garden: Visions for Contemporary Islamic Garden Design

\section{INTRODUCTION}

Historically, Muslim has ruled Spain from early 8th century until 1492 (AbduNoor, 2005). Al-Andalus, the Muslim political sovereignty in Spain was governed by the Umayyad caliphs in Damascus until 750 when the Abbasid dynasty came to power in the East. Abd al-Rahman ibn Mu'awiyah ibn Hisyam ibn Abd al-Malik ibn Marwan or Abd ar-Rahman I (756-788 A.H. 139-172), the last surviving member of the Umayyad dynasty, escaped from Damascus and fled to Spain. He established an independent Umayyad state (Dodds, 1992) in Cordoba, thus became the founder of Umayyad dynasty there. He built the first garden called Al-Rusafa (Ruggles, 2008; Almagro \& Ruggles, 2007; Dodds, 1992) in the city of Al-Rusafa, Cordoba based on what he saw at Damascus, Syria (Abdine, 1986; Lehrman, 1980) that had influences from the Umayyad dynasty during the caliph Hisham's reign from 724-743 (Ruggles, 2008), and if the dating is correct, this garden was the earliest Islamic garden exemplar (Almagro \& Ruggles, 2007; Grabar, 1980). This was also the moment when a number of small Muslim dynasties bloom.

Al Rusafa garden is a large garden enclosed by mud-brick walls. In the centre, an elevated square pavilion of stone with four sides' access is located (Almagro \& Ruggles, 2007). Elevating a building on an intersection allows elevated views and vistas of the surrounding garden as well as an expression of sovereign power. This garden did not follow the four-part layout that became ubiquitous in most of the Islamic gardens Dodds, 1992; Ruggles, 2008). Its orchards were watered by a pipe which ended in a pool, over which there was a lion covered in pure gold. The water entered through its hindquarters and poured out through its mouth (Al-Makkari, 1840).

Another type of Andalusian garden is the open courts and gardens (Abdine, 1986), which are found throughout the south of Spain including Cordoba, Seville and Málaga. Madinat al-Zahra is one of the examples of an open court garden built by the first Spanish Umayyad caliph, Abd al-Rahman III (North African reverts to Islam) located in the royal city of Madinat al Zahra' (Doak, 2009). This luxurious palace garden of Madinat al-Zahra is built in the agricultural zone (Ruggles, 2008) on three stepped terraces on the sloping skirt of a mountain (Ruggles, 1992) in the royal city, using materials that reflected the king's wealth such as marble, bronze, silver, and gold (Foret, 2009). The garden consists of several palaces and planted with palms, olives, oranges, jasmine, yellow roses and pomegranate (Abdine, 1986; Almagro \& Ramón-Laca, 2007; Lehrman, 1980). "Madinat al-Zahra' resembles that of Abbasid cities like Samarra which tended in their maze-like form. The planning shows the impact of Abbasids, decorated from an indigenous Spanish Islamic tradition" (Dodds, 1992).

Accordingly, it became the model of subsequent palace estates built in Cordoba. It had influences from Iran and Mesopotamia gardens. The renowned 
term Mesopotamia was first used by the Greek to refer to the area between the Tigris and Euphrates rivers (Phillips, 2010). Madìnat al Zahrā' had enclosed courtyard complete with essential elements in an Andalusian Islamic garden such as pavilions, sculptures, arcades and terraces lined with trees and flowers, watered from rivers and hillside streams (Abdine, 1986; Lehrman, 1980).

\section{OBJECTIVE \& METHODOLOGY OF THE STUDY}

The main objective of the study is to determine the physical characters of the Andalusian garden to be emulated into contemporary Islamic garden design. The methodology adopted is mainly content analysis and library search that emphasised on the theories and principles of the Andalusian garden, as well as reference to the Quran, Hadiths and related literature written by Islamic scholars.

\section{THE PARADISIACAL CONCEPT IN THE ANDALUSIAN GARDEN}

Andalusian garden has a paradisiacal concept in the sense that it is filled with scented flowers, singing birds and water-wheels with entertaining sound (AlMakkari, 1840). There are three types of Andalusian garden (Harvey, 1974); first, walled courtyard or patio, domestic and inward looking (Court of the Myrtles (1334-1354). Second, the large gardens (Jennat al-Arif) or the Generalife or 'The paradise of the Architect' (Fromherz, 2010). The third, the ordinary garden (Harvey, 1974). It is also called Royal Garden, referring to its construction of high ranking courts and splendid royal palaces, the Morphological Garden, referring to the aroma, color and aesthetic hedonistic ends and multiple uses of plants; used for medicine, decoration, food, agriculture, dyes, perfumes, and cosmetics (Ruggles, 2008). Essential elements in the garden are water, plants, trees, sculptures and pavilions while figural sculpture is very rare in Islam (Harvey, 1974).

Andalusian garden also exhibits the sense of intimacy and privacy; remote from the outside world; delicacy and subtle use of water as the major conceptual focus of a paradisiacal garden world; astounding variety of low, musical sounds created by many tiny splashing jets and the last is the intensity created by contrasts between large and very tight spaces, and the contrast between deep shade and bright light (Nevins, 1988). Lastly, the garden is always around pools or water features (Almagro \& Ramón-Laca, 2007).

The Alhambra is a majestic complex of administration with several courtyard gardens in different sizes. It is the Islamic palatial and residential architecture (Rabbat, 1985) where a great emphasis is given to the inward orientation (Attia, 2006) around the court which appears as the typical Islamic inclination (Omer, 2009). The Alhambra is no more than a palace in the same sense as Versailles and Buckingham Palace. The palace was more like a synthesis of early Islamic palaces and a fortified town which comes from both Roman and $2^{\text {nd }}$ century central Asian traditions. The palace is saturated with divine codes. 
Zainab Abdul Latiff, \& Maheran Mohd Yaman

Revisiting Andalusian Garden: Visions for Contemporary Islamic Garden Design

There is no division between the sacred and secular life of the code, even the earthly power of the sultan is subordinate to that of god. "God alone is the Victor", the motto of the Nasrid is present on the walls of the Alhambra (Dickie, 1992).

The Court of the Lions has always been praised for the balanced composition or architecture, vegetation and water (Rabbat, 1985). The longer east-west axis in the court is defined by projecting pavilions sheltering fountains whose overflow draining through channels to the centre, forms two of the rivers of paradise. A central pond in the middle of the Court of the Lions and the Court of Myrtles symbolizes soul purification, reflection, contemplation, continuity, nucleus, animation, delicacy, infinity and symmetries. Bowls in the courts let water flows continuously in carved channels made of stone before spilling into rectangular pond (Attia, 2006). Meanwhile, in the large garden of the Generalife, the water channels are diagonal that run across the steep hillside to fall into patio gardens (Attia, 2006). There are also three layers of water stairway that provide dramatic views over the landscape, juxtaposed with the visual play of water and stone. The dynamism of water management in the Court of the Lions is accounted as purifying the soul, contemplating God's creation of the universe (Lehrman, 1980) and to give life to the inanimate. The dynamism of water management is put into the physical form of water fountains, channels, an underground cistern to catch rainwater, small jets, underground reservoirs, small canals and tanks.

The availability of water in abundance was also intelligently used as a cooling agent within an enclosed space such as in the Patio de la Acequia. Stagnant water feature in the patio is essential as reflecting agent; reflecting the sky, surrounding architecture and plants. She mentioned that, in order to ensure the movement of water in the small-area garden in the Court of the Lions, pumps and hydraulics are used showing the flexibility and the sense of regionalism or space. Rainwater is captured by gables on the roof to each tree with minimal evaporation and water loss (Carroll, 2003). The Court of the Lions is a water clock-fountain, regarded as a rejuvenating agent that adheres strictly to the management of water, use water only when people actually use the space. The lion statues were designed in such a way that it will shoot water both ways when the shadow casts on them to remind the Muslim of zuhur prayer time, and the water that circulates is clean enough for ablution.

The principal of spirituality was well displayed by the repetitive inscriptions of geometric and calligraphic decorations on the walls of the Court of the Lions as an Islamic iconography (Foret, 2009; Mirza, 2014; Rabbat, 1985). It is important to note that, Kufic is used for calligraphies from the Qur'an, which tend to be high up on the walls nearer to the heaven, while the poetry is further from heaven nearer the ground. These repetitions of inscriptions on the walls of the Alhambra symbolize the instability of the political environment of the Nasrids due to an endless war with other Muslim dynasties and non-Muslim dynasties, the Castilla and Aragon (Ahmad, 2004). Built primarily by Muhammad V, the 
PLANNING MALAYSIA

Journal of the Malaysia Institute of Planners (2017)

Court of the Lions reflected cultural syncretism (Ahmad, 2004). Today, the routes are no more the same, windows have been converted into doors, beds into passageways and the two palaces of Alhambra and Generalife are now connected (Dickie, 1992). The whole palace complex was the setting of the mysterious real and imaginary worlds of splendour, intrigue and romance.

For most scholars, the Court of the Lions was seen as having the paradisiacal image of four gardens (Ali, 2000). Such interpretation also can be found in Persian gardens however; the court was not conceived in the image of Paradise (Rabbat, 1985). It was an earthly garden for earthly pleasure imitating the tradition of the Roman of villa rustica. The purpose of the court was not to glorify materials or feats of engineering, or even to impress the subjects of the King but to provide its inhabitants with an intimate, entertaining living space (Grabar, 1990). It displays profoundly the traditional architecture not technology (Ahmad, 2004) which was already found during Achaemenid.

There is no evidence in the first four centuries of Islam that gardens were consciously designed with four quadrants and four water channels in order to imitate the paradise. Most gardens belonged to palaces where the environment was decidedly impious, characterized by the political display and other immoral acts that are forbidden to be practiced by Muslims (Ruggles, 2008). Even the 12 lion statues in the centre of the Court of the Lion was built by the Jews. This is supported by the facts that the Jews who used to live within Muslims for hundred years, had used to the culture of Moorish Spain and considered it something they shared with Spanish Muslims. It is a symbol of so-called harmony coexistence of Christians, Muslims and Jews; three faiths lived together in peace and harmony. Courtyards are private and secured gardens constructed to optimize a small space located on a small scale of area normally in a building fully occupied by rich spatial elements derived from the description of paradise from the Qur'an. Strict geometric patterns (Lehrman, 1980; Ruggles, 2000) also promote a sense of belonging (Lehrman, 1980).

This principle of balance and harmony are aligned between vegetation and architecture in the sense that they did not conflict with each other (Lehrman, 1980). For example, in the Court of Myrtles, aromatic bushes are planted in parallel to the walkways (Attia, 2006) and sometimes in geometrical and maze layout (Lehrman, 1980), orange trees are planted in four corners of four axial canals. Consequently, the truth becomes the hidden baraqah for the old building which survives till today from the $14^{\text {th }}$ century, when without the Muslim, the building also acted as a reminder of the Oneness as angels still conduct $d z i k r$ from the walls decorations. Theoretically this is known as 'spirit of a place' alive for centuries. It was not realized by the Christian's Spaniard of Ferdinand and Isabelle due to their culture of siesta which destroyed them till today. It is interesting to find that these inscriptions show exactly the intention of its builders (Hoag, 1977). 
Zainab Abdul Latiff, \& Maheran Mohd Yaman

Revisiting Andalusian Garden: Visions for Contemporary Islamic Garden Design

The Alhambra was developed by the Moors in 1238-1492 (Lehrman, 1980). It has the influences from Europe, the Almohads, the Fatimids and the Eastern Islamic world (Ahmad, 2004). The layout of the magnificent Alhambra conceitedly organised around an inner courtyard. It presents to the outside world high windowless walls interrupted only by a single low entrance that emphasised its perspective and ensemble the successful integration of water and built environment (Attia, 2006). It promotes passive ventilation system; capture the wind and reduce heat where the designer can manipulate the site and create a variety for water, vegetation and pavement composition (Attia, 2006). For example, in the Court of Myrtles, built by Muhammad V, there is a rectangular courtyard with a rectangular pool in the middle (Attia, 2006) with a dodecagonal basin is located at the bottom of the twelve stone lions (Attia, 2006; Hoag, 1977).

The settings and arrangement of the animate and inanimate in this small area garden of Court of Myrtles (Harvey, 1974) are done in a balanced composition that occupies the small space of the garden to the maximum. In order to optimize the space usage, the layouts and settings of the area are always done in such a way to reach as many geometric patterns as possible by employing quadripartite lines (Attia, 2006), squares, perpendiculars, dodecagonal, axial, parallel, axes; longitudinal, transversal and symmetries.

The lavish decorations by the mean of geometric designs and muqarnas vaulting in the garden represent the infinite and the divine (Foret, 2009). The decorations of the chambers enhanced the idea of abundance (Abdine, 1986; Foret, 2009). These abstract patterns were seen as agents of the spiritual world. The decorations are lively and set in a space allocated for contemplation as one of the ultimate forms of pleasure that were attained through God and seen through the abstract patterns of the geometric decoration and muqarnas vaulting (Grabar, 1990). The muqarnas are a representation of the rotating dome of heaven, which in turn represents the mastery of time. The inscriptions on the walls directly suggest the illusion of heaven.

King Muhammad V has magnificently designed the Alhambra with the profuse usage of water, rectangular pools with water reflecting the sky and the abundance of water in the garden itself. The value of proportion, spiritual refreshment, paradisiacal, luxury, spaciousness, luminosity and relaxation that mirror the ideal human condition that deeply concerned with inner soul development is established. The court consists of four principle-surrounding chambers of the Hall of the Muqarnas, the Hall of Justice, the Hall of Abencerajes and the Hall of the Two Sisters (Hoag, 1977).

Besides, the court and all the spaces in it are built in such a way for people to sit on or near to the floor (Hoag, 1977). "This explains why...all the other fountain basins...are flush with the marble floors...reflections on the water are also best observed while seated beside them...hence the verses around the central fountain basin" (Hoag, 1977). Plantings of flowers, bushes and small trees were 
also once being nearer to the eye level of persons seated in the porticoes but the view to the court are not concealed. However, there are no trees planted in the court (Attia, 2006).

Domestic courtyards (Lehrman, 1980; Omer, 2009) in the Andalusian garden emulate as much the characteristics of paradise as mentioned in the Qur'an in terms of its layout, settings and arrangements of its spatial elements. The stone paving, white stuccoed walls, bright and dark colored tiles (Lehrman, 1980), potted plants for the minimal use of water (Lehrman, 1980), white marbles and trees of cypress, orange and palm that were planted in rows to show infinite rhythmic at each side of a small pool with trickling fountain is a reminder of the paradise of Muslim. There is also a channel that flows into a basin with a pavilion in the centre of the courtyard (Lehrman, 1980). In order to remind one of the paradise, a small bower is placed at the junction of paths that were formed from the cypress trees. The enhancement of privacy and shade is successfully reached in this generous garden courtyard. The courtyard garden is a cool and shady as the trees and plants were so dense that they do not allow the sunrays to reach the ground thus providing a gentle wind all day (Attia, 2006).

The Generalife is a city within a city, was built in the time of the King of Granada, Muhammad II (1273-1302), and later enlarged by Kings Muhammad III (1302-1309) and Isma'il I (1313-1325). Besides featuring Granada's Muslim legacy, it was also a city of scholars ${ }^{32}$ such as al-Mazini, ibn Tufayl, ibn Rushd, ibn Zuhr, ibn Khaldun, ibn Batuta and ibn al-Khatib to name a few. Its setting on the elevated spot with good fertile red soil displays its majestic political and religious complex. The Generalife is a series of gardens and pavilions; known as the summer retreat of the Sultan or the court of irrigation (Attia, 2006).

The quadripartite design is mentioned more than one time in the Qur'an hence become a common design for Islamic gardens from Spain to Mughal India (Carroll, 2003; Lehrman, 1980). In order to resemble paradise, evergreen, shady, colourful and lavish plants and vegetation are planted such as artichokes, myrtle and cyprus. These plants provide structure and lushness year-round such as in the Court of the Alcazar, Seville (Carroll, 2003). The combination of natural and built environment elements of the garden is shown when climbing vines (Foret, 2009) are sometimes let to cover the wall as a finishing element to make it look like high evergreen hedges to maintain coolness such as in the modern design of urban plazas (Nevins, 1988). Aromatic plants are also planted to form Arabic calligraphy in the garden, besides being used for culinary purposes (Lehrman, 1980).

Ground covers are normally planted under the tall trees (Ruggles, 2000). These ground covers, sunken beds or living carpet design make use of both lush and dry landscape (Ruggles, 2000). It is designed and arranged in such a way that the plants are planted with the same level with the adjacent water feature thus water that was captured from the adjacent water feature can be used minimally 
Zainab Abdul Latiff, \& Maheran Mohd Yaman

Revisiting Andalusian Garden: Visions for Contemporary Islamic Garden Design

(Hoag, 1977). Therefore, an Islamic garden should be harmless for people or visitors to sit on the ground while enjoying the variety, beauty and aromatic smell (Ali, 2000) of the garden as picking fruits that hang low within the reach of hands (Ali, 2000). Fruit trees are arranged in lines of garden walks and parapets (Lehrman, 1980). Plantation lent additional colour and fragrance that use any water runoff to irrigate the garden (Lehrman, 1980).

Among the accessories in the Andalusian garden are solid benches that stand on their own and sometimes are attached to a wall. There are also pots of terracotta, flower beds (Lehrman, 1980), vases of coloured glaze, unglazed tiles that were formed and paved and capped walls. The walkways are faced with tiles, bricks, earth-coloured and smooth pebbles laid in a geometric pattern. There are also fountains and paths and edged steps (Lehrman, 1980). Courtyards in the Andalusian garden has a minimal use of plants and water in the most purposeful ways. The focus is given more on living spaces while leaving the native landscape dry. Andalusian garden offers shade and flexibility within a built environment. The lushness is created without a great deal of water thus highlighting the uniqueness of the space and makes the urban fabric feel grounded in place. Gardens on the hilly area are terraced with an orchard to mitigate erosion and surface runoff. It also produces the maximum effect by using minimum expenditure of water (Harvey, 1974). The Generalife is exhibited as planted with trees and shrubs and brightly colourful flowers with penetrating perfumes. Cypress trees are used as its principle tree that lived for 600 years (Harvey, 1974).

The Alhambra is known for its sustainable water management planning in the city. The Andalusian garden is full of water. Water is the binding thread that ties everything together. Fountains in the centres of the Hall of the Abencerajes and of the Two Sisters drain again into the centre, symbolizing the other two rivers of the paradise. The uses of water in the palaces fountains and watercourses are dynamic in terms of its design, which are rightly to the longevolving tradition of ornamental and palatial water usage in the Mediterranean and Persia, both in the pre-Islamic and Islamic periods (Grabar, 1980).

Having a royal city in a large urban complex can also be seen in the other parts of the world such as Rome, Byzantine, Constantinople, Samarra and monastery garden. Six features of the Domus Aureus from the mediaeval ages had influenced much on the Islamic palaces. They are grand size, different kinds of water (pools, fountains, hot, cold), the luxury of surfaces and artificially composed nature (as in gardens or agriculture). There are three types of decorations namely vegetal, geometric and epigraphic. The Alhambra of today is a modification. This delicate and fragile palace was made essentially for temporal power and worldly pleasure. Its decoration is flawless but not new. It represents the mixture of previous cultures that the Nasrids had to balance politically and culturally. The decline of the dynasty in 1453 had also marked the end of the Muslim empire in Spain and Catholicism was spread to every corner of the world. 


\section{CONCLUSION}

Andalusian garden is a metaphor of garden which is a reward for those who practice good deeds as a garden on planet earth; it is far from the real paradise gist as described in the Qur'an. The real garden attributes are varying according to the Muslim culture all over the world and is determined by weather and local practices. "Among the examples of Islamic architecture under the sway of light, the Alhambra at Granada sets the first rank. The Court of Lions in particular sets the example of stone transformed into a vibration of light; the lambrequins of the arcades, the friezes in muqarnas the delicacy of the columns which seem to defy gravity, the scintillation of the roofs in green tile-work and even the water jets of the fountain, all contribute to this impression. By analogy, one can say of Muslim architecture that it transforms stone into light which, in its turn, is transformed into crystals" (Nasr, 1987). Andalusian garden shows an attempt of spiritual and sacred essence of paradisiacal environment emulation by its designers at the time. However, to truly adhere to Islamic principles is not enough by integrating the paradise description on garden's design alone, however, it must instil the senses of tawhid, mizan, fitrah and khalifah (Abdul Latiff \& Mohd Yunus, 2016). Into it as everyone are answerable to His Creator for how he has used the countless blessing rewarded upon him. Not to mention that, Islam forbids any unlawful act or elements in any circumstances including in designing a garden that disgrace Islam and create misinterpretations about the religion.

\section{REFERENCES}

Abdul Latiff, Z., \& Mohd Yunus, M. Y. (2016). The Islamic Garden design principles: thoughts for the 21st century. Research Journal of Fisheries and Hydrobiology, 11(3), 175-178.

Abdine, A. E. (1986). The Islamic garden in Andalucía, Spain. Environmental Design: Journal of the Islamic Environmental Design Research Centre, 1, 76-77.

Abdu-Noor, M. I. (2005). Sunset in the Gardens of al-Andalus. Nebula, 2(1), 1-11.

Ahmad, I. (2004). The Bride Unveiled: Influences on and Interpretations of the Alhambra.

Ali, A. Y. (2000). The Holy Qur'an: original Arabic text with English translation \& commentary. Saba Islamic Media.

Attia, S. (2006). The role of landscape design in improving the microclimate in traditional courtyard buildings in hot arid climates. In Proceedings of 23rd International Conference on Passive and Low Energy Architecture - PLEA 2006 (Vol. V(1)) (pp. 61-67). Geneva, Switzerland.

Almagro, A., \& Ramón-Laca, L. (2007). Introduction to the catalogue of Andalusian Gardens. Retrieved on June 15th, 2015 from http://www.doaks.org/resources/ middle-east-garden-traditions/andalusian-gardens/introduction-to-andalusiangardens. 
Zainab Abdul Latiff, \& Maheran Mohd Yaman

Revisiting Andalusian Garden: Visions for Contemporary Islamic Garden Design

Almagro, A., \& Ruggles, F. D. (2007). Early Islamic Gardens in Syria, Jordan and Iraq. Retrieved on January 2nd, 2016 from http://www.doaks.org/resources/middle-eastgarden-traditions/early-islamic-gardens-of-greater-syria/introduction.

Al-Makkari, A. I. M. (1840). The History of the Mohammedan Dynasties in Spain (Vol. 1). London: Harvard College Library.

Carroll, M. (2003). Earthly paradises: ancient gardens in history and archaeology. Los Angeles: Getty Publications.

Dickie, J. (1992). The palaces of the Alhambra. In J. D. Dodds (Ed.) Al-Andalus: the art of Islamic Spain, p.135-151. New York: The Metropolitan Museum of Art.

Doak, R. (2009). Empire of the Islamic World. New York: Chelsea House Publisher.

Dodds, J. D. (1992). Al-Andalus: the art of Islamic Spain. New York: Metropolitan Museum of Art.

Foret, A. S. (2009). Reflections on Pleasure: The Fourteenth-Century Alhambra (Master's thesis). Southern Methodist University.

Fromherz, A. J. (2010). Ibn Khaldun: Life and Times. Edinburgh: Edinburgh University Press.

Grabar, O. (1990). From Dome of Heaven to Pleasure Dome. Journal of the Society of Architectural Historians, 49(1), 15-21.

Grabar, O. (1980). Symbols and signs in Islamic architecture. In G. K. Jonathan (Ed.), Architecture as symbol and self-identity. Philadelphia: Aga Khan Award for Architecture

Grabar, O. (1976). The Alhambra. Cambridge: Harvard University Press.

Harvey, J. H. (1974). Spanish gardens in their historical background. Garden History, 3(1), 7-14.

Hoag, J. D. (1977). Islamic architecture. H. N. Abrams.

Lehrman, J. B. (1980). Earthly paradise: garden and courtyard in Islam. University of California Press.

Mirza, M. (2014). Paradise on Earth: Designing a Socially Sustainable Landscape in Northwest Pakistan (Master's thesis). University of Manitoba Winnipeg, Canada.

Nasr, S. H. (1987) Islamic Art and Spirituality. Albany: SUNY Press.

Nevins, D. (1988). Learning from the Hispano-Arab garden. ANTIQUES, 133(3), $692-$ 703.

Omer, S. (2009). The history and character of the Islamic built environment. Kuala Lumpur: Arah Pendidikan Sdn Bhd.

Phillips, D. A. (2010). Syria. New York: Chelsea House Publisher.

Rabbat, N. (1985). The Palace of the Lions, Alhambra and the Role of Water in its Conception. Environmental Design: Journal of the Islamic Environmental Design Research Centre, 2, 64-73.

Ruggles, F. D. (1992). Gardens of the Alhambra and the concept of the garden in Islamic Spain.

Ruggles, F. D. (2000). Gardens, landscape and vision in the palaces of Islamic Spain. University Park, Pennsylvania: Pennsylvania State University Press.

Ruggles, F. D. (2008). Islamic gardens and landscapes. University Park, Pennsylvania: Pennsylvania State University Press.

Zaimeche, S. (2004). Granada-The Last Refuge of Muslims in Spain. Foundation for Science, Technology and Civilization. 